Article

\title{
Techno, Economic and Environmental Assessment of a Combined Heat and Power (CHP) System-A Case Study for a University Campus
}

\author{
Khuram Pervez Amber 1,2,*, Tony Day ${ }^{2}$, Naeem Iqbal Ratyal ${ }^{3}$, Adnan Khalid Kiani ${ }^{4}$ \\ and Rizwan Ahmad ${ }^{4}$ \\ 1 Department of Mechanical Engineering, Mirpur University of Science and Technology (MUST), \\ Mirpur 10250 (AJK), Pakistan \\ 2 Faculty of Engineering, Science and the Built Environment, London South Bank University, \\ London SE1 0AA, UK; tony.day@ierc.ie \\ 3 Department of Electrical Engineering, Mirpur University of Science and Technology (MUST), \\ Mirpur 10250 (AJK), Pakistan; naeemratyal@must.edu.pk \\ 4 School of Electrical Engineering and Computer Science, National University of Sciences and \\ Technology (NUST), Islamabad 44000, Pakistan; adnan.khalid@seecs.edu.pk (A.K.K.); \\ rizwan.ahmad@seecs.edu.pk (R.A.) \\ * Correspondence: khuram.parvez@must.edu.pk; Tel.: +92-341-596-4460
}

Received: 3 April 2018; Accepted: 1 May 2018; Published: 3 May 2018

\begin{abstract}
Universities in the United Kingdom that have installed Combined Heat and Power (CHP) technology are making good moves towards achieving their $\mathrm{CO}_{2}$ reduction targets. However, CHP may not always be an economical option for a university campus due to numerous factors. Identification of such factors is highly important before making an investment decision. A detailed technical, economic, and environmental feasibility of CHP is, therefore, indispensable. This study aims to undertake a detailed assessment of CHP for a typical university campus and attempts to highlight the significance of such factors. Necessary data and information were collected through site visits, whereas the CHP sizing was performed using the London South Bank University (LSBU) CHP model. The results suggest that there is a strong opportunity of installing a $230 \mathrm{~kW} \mathrm{CHP} \mathrm{that} \mathrm{will}$ offset grid electricity and boilers thermal supply by $47 \%$ and $75 \%$, respectively, and will generate financial and environmental yearly savings of $£ 51 \mathrm{k}$ and $395 \mathrm{t} / \mathrm{CO}_{2}$, respectively. A wider spark gap decreases the payback period of the project and vice versa. The capital cost of the project could affect the project's economics due to factors, such as unavailability of space for CHP, complex existing infrastructure, and unavailability of a gas connection.
\end{abstract}

Keywords: combined heat and power; CHP; university campus; carbon emissions; economic feasibility

\section{Background}

Higher Education Institutions (HEI) are key components of education systems across the globe, transcending international borders, socio-political regimes, and economic systems [1]. The Higher Education (HE) sector of the United Kingdom plays a vital role in the country's economy with an economic contribution of $£ 39.9$ billion per year [2]. But, on the other hand, because of its increasing energy demand, the HE sector is responsible for considerable environmental pollution. In 2005/06, the sector emitted nearly 2.15 million tonnes of Carbon Dioxide $\left(\mathrm{CO}_{2}\right)$ emissions [3].

Owing to the significance of this matter, the HE Funding Council for England (HEFCE), in 2010, published its Carbon Reduction Target and Strategy for the HE sector. This document aims to reduce 
carbon emissions in HE by linking carbon to capital funding. It further develops a carbon reduction strategy by setting a carbon reduction target of $43 \%$ for 2020 from a 2005/06 baseline. Institutions are required to produce carbon plans and to demonstrate progress against those plans [4].

Figure 1 shows the sector's carbon emissions since 2005/06. It is apparent that carbon emissions were increasing till 2009/10, but after introduction of the HE sector's carbon reduction targets of $43 \%$ in 2010, the emissions started decreasing and were observed as being 19\% lower in 2015/16 when compared to the base year's emissions. This decreasing trend is the result of installation of renewable and clean energy technologies by the universities and energy efficiency initiatives. However, yet, the current average annual rate of decrease in emissions is $1.9 \%$, which clearly suggests that the sector, despite its solid carbon reduction initiatives, will be missing its 2020 target of $43 \%$ by a big margin [5].

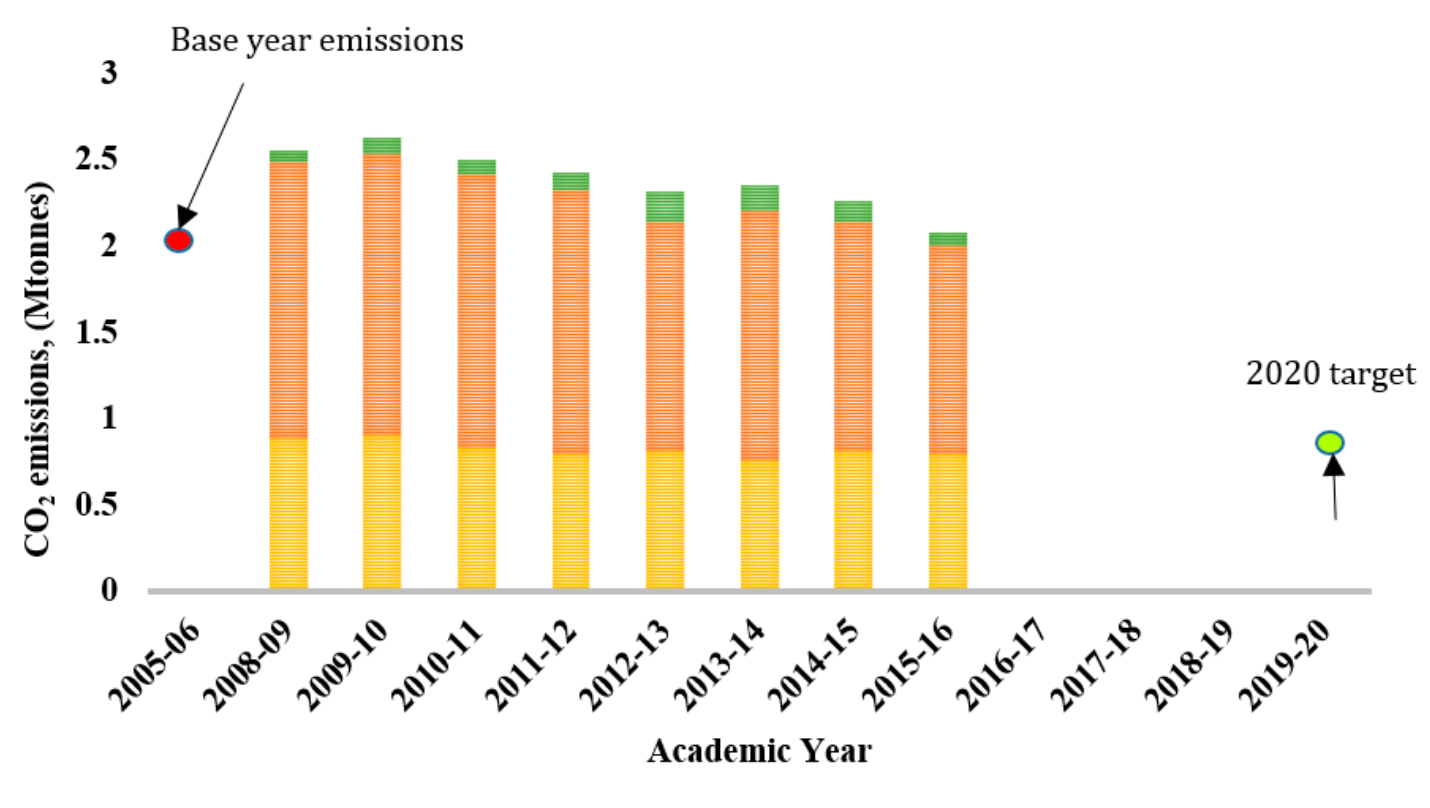

$\llbracket$ Natural Gas Emissions $₫$ Grid Electricity Emissions 쁠 Other Fuels Emissions

Figure 1. Yearly variation in Higher Education (HE) sector's Carbon Dioxide $\left(\mathrm{CO}_{2}\right)$ emissions [6].

Grid electricity and natural gas are the two main sources for sector's carbon emissions, with a share of $63 \%$ and $33.3 \%$, respectively [6]. This suggests that offsetting the grid electricity through onsite electricity generation using a clean and reliable alternative technology could result in significant carbon savings.

HEIs approach to achieving this target is to identify and to implement carbon reduction projects that maximize both the direct (financial) and indirect benefits, whilst minimizing the capital and operational costs. Through these carbon reduction projects, universities are investigating a number of renewable and clean energy technologies such as solar, wind, heat pump, and Combined Heat and Power (CHP). CHP is the simultaneous generation of usable heat and power (usually electricity) in a single process [7]. Electricity is generated on or close to the end user's site, allowing capturing and using the resulting waste heat for site applications [8]. A comparison between CHP and a conventional heat and power system is shown in Figure 2. It is apparent that a CHP offers higher efficiency with an overall efficiency of $80 \%$ as compared to a $55 \%$ overall efficiency of a typical gas power plant. 


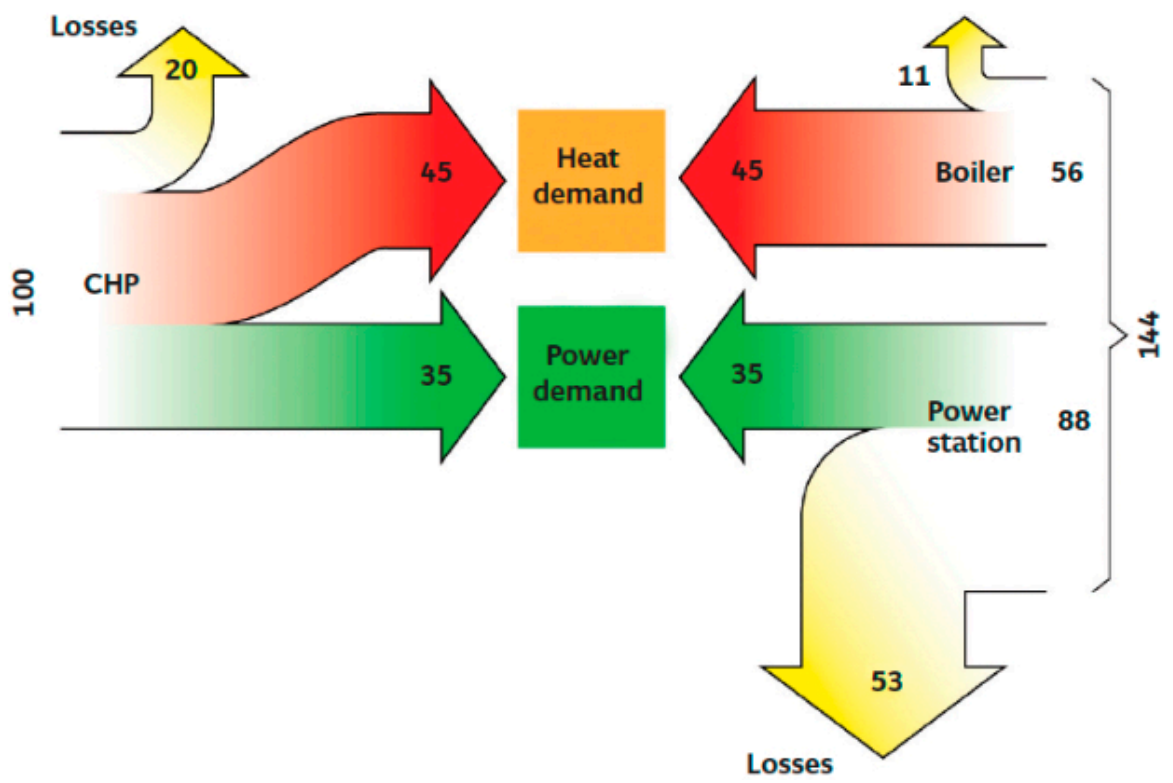

Figure 2. Comparison between Combined Heat and Power (CHP) and a Separate Heat and Power System [9].

The HE sector of United Kingdom is comprised of about 161 universities. The sector offers strong potential for renewable and clean technologies. In 2014-15, the share of renewable technologies towards the sector's total energy consumption was found to be $0.49 \%$ only. Among these, energy that was generated from biomass, wind, and solar PV was $63 \%, 18 \%$, and $11 \%$, respectively, whereas, the remaining $7 \%$ was generated from other renewable resources, such as biofuels. On the other hand, the CHP plants (usually categorized as clean technology) met 13\% energy demand of the sector in 2014-15, which is 3.1\% higher when compared to 2011-12. Towards the end of 2011, 49 out of 161 universities had installed CHP systems. This number jumped to 67 in 2015/16, showing universities great interest in this technology. In 2015-16, CHP systems generated 33\% more energy when compared to 2008-09 figures [10]. Figure 3 shows an annual increase in the sector's CHP energy generation.

This gradual increase in yearly energy generation from CHP systems could be attributed to the increased number of $\mathrm{CHP}$ installations in the universities.

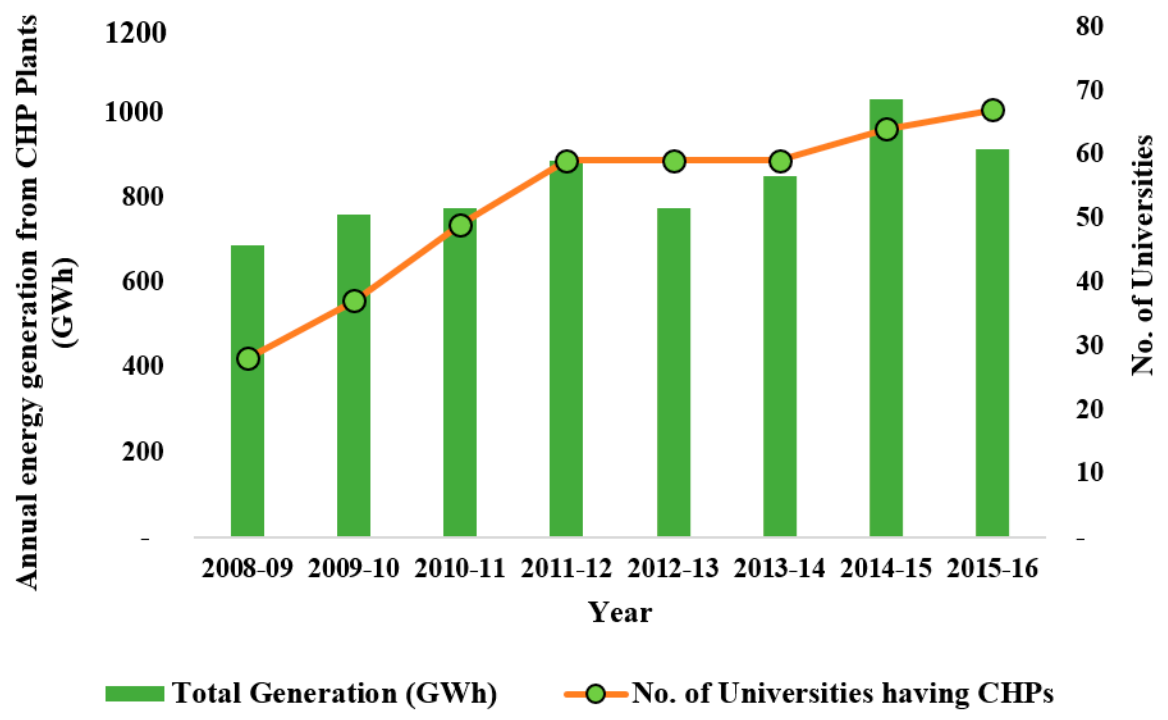

Figure 3. Yearly variation in CHP number of installations and electricity generation [10]. 
Table 1 shows the top eleven universities in terms of CHP energy generation. It is apparent that the University of Liverpool generated the highest CHP energy with a share of $14 \%$ with the University of Edinburgh and the University of Birmingham at second and third positions, with shares of $11 \%$ and $10 \%$, respectively. Top five universities generated $50 \%$ of the sector's total CHP energy generation.

Table 1. Highest CHP energy generation Universities [10].

\begin{tabular}{ccccc}
\hline University & $\begin{array}{c}\text { Thermal } \\
\text { Generation (GWh) }\end{array}$ & $\begin{array}{c}\text { Electricity } \\
\text { Generation (GWh) }\end{array}$ & $\begin{array}{c}\text { Total CHP } \\
\text { Generation (GWh) }\end{array}$ & $\begin{array}{c}\text { Share of Sector's } \\
\text { Total Generation }\end{array}$ \\
\hline The University of Liverpool & 79 & 49 & 128 & $14 \%$ \\
The University of Edinburgh & 55 & 41 & 96 & $11 \%$ \\
The University of Birmingham & 55 & 37 & 92 & $10 \%$ \\
The University of Warwick & 39 & 40 & 80 & $9 \%$ \\
The University of East Anglia & 37 & 14 & 51 & $5 \%$ \\
The University of Southampton & 20 & 22 & 42 & $4 \%$ \\
The University of Dundee & 15 & 20 & 35 & $4 \%$ \\
The University of York & 14 & 18 & 32 & $3 \%$ \\
The University of Aberdeen & 24 & 8 & 23 & $3 \%$ \\
The Queen's University of Belfast & 11 & 12 & 23 & $3 \%$ \\
The University of Stirling & 11 & 12 & & \\
\hline
\end{tabular}

Yet, there are 95 universities in the UK where CHP technology has not been installed. This clearly demonstrates that despite its higher efficiency and the higher carbon savings potential, the CHP technology may not be feasible for some university campuses based on numerous barriers. Such barriers were identified by Amber and Parkin [11] through a questionnaire that was sent to the energy managers of the UK universities. Among these, the top barrier identified were the site constraints, such as buildings sensitivity, low energy demands, and complex infrastructure. These site constraints will be different in almost all cases, and may strongly influence the optimum sizing of CHP system. For example, the existing electrical and mechanical infrastructure should be studied thoroughly in order to make sure that electrical and mechanical integration of CHP will be feasible and it will not trouble the existing system and the building operation. Other constraints may include buildings sensitivity, building material, and access to the plant room and switch room, and the availability of space inside the plant room and switch room. Building's sensitivity here is referred to the sensitive nature of the activities taking place, e.g., medical research centers where electricity supply cannot be switched off, even for a shorter period of time due to the sensitive nature of activities taking place inside. Such buildings may have good thermal and electrical demands, but due to their sensitivity, CHP integration in such buildings may not be allowed by the University's management.

It is of great importance that CHP's feasibility must be completed after taking into account all such site constraints that could affect the economics of the project. Therefore, a detailed techno, economic, and environmental assessment based on such site constraints is indispensable, which should help the decision makers in making an appropriate decision [12]. In most cases, such assessment is done by the consultancy firms that charge a handsome amount for this crucial activity. The output of this feasibility study strongly depends on the professional expertise and the resources of the consultancy firm.

For a CHP project to be an economical option for the university, building(s) energy demands play the vital role [13]. Buildings with high and year-round electrical and thermal demands offer strong potential for CHP installation [14]. Another key factor that could affect the economic feasibility of a CHP scheme is the spark gap. Spark gap is the difference between the electricity and natural gas tariff. The higher the spark gap, the higher financial savings could be expected from the CHP plant, thus making it an economically viable option [15]. A spark gap of three or more is usually desired for a CHP project to be economical [16]. The capital cost of the project is also a dominant factor that could affect a project's economic feasibility based on the site constraints discussed earlier [17].

Owing to the significance of this subject, this study aims to highlight the importance of such crucial factors by undertaking a detailed technical, economic, and environmental feasibility of CHP for a university campus that was located in London, UK. It is anticipated this study will be helpful for the 
building services engineers in understating the direct and indirect effect of variety of site constraints on the economics of a CHP project. Methodology and results of this study are presented in detail in Section 2. Section 3 shows the conclusions of the study.

\section{Methodology}

Figure 4 demonstrates the methodology that was adopted while performing this study.

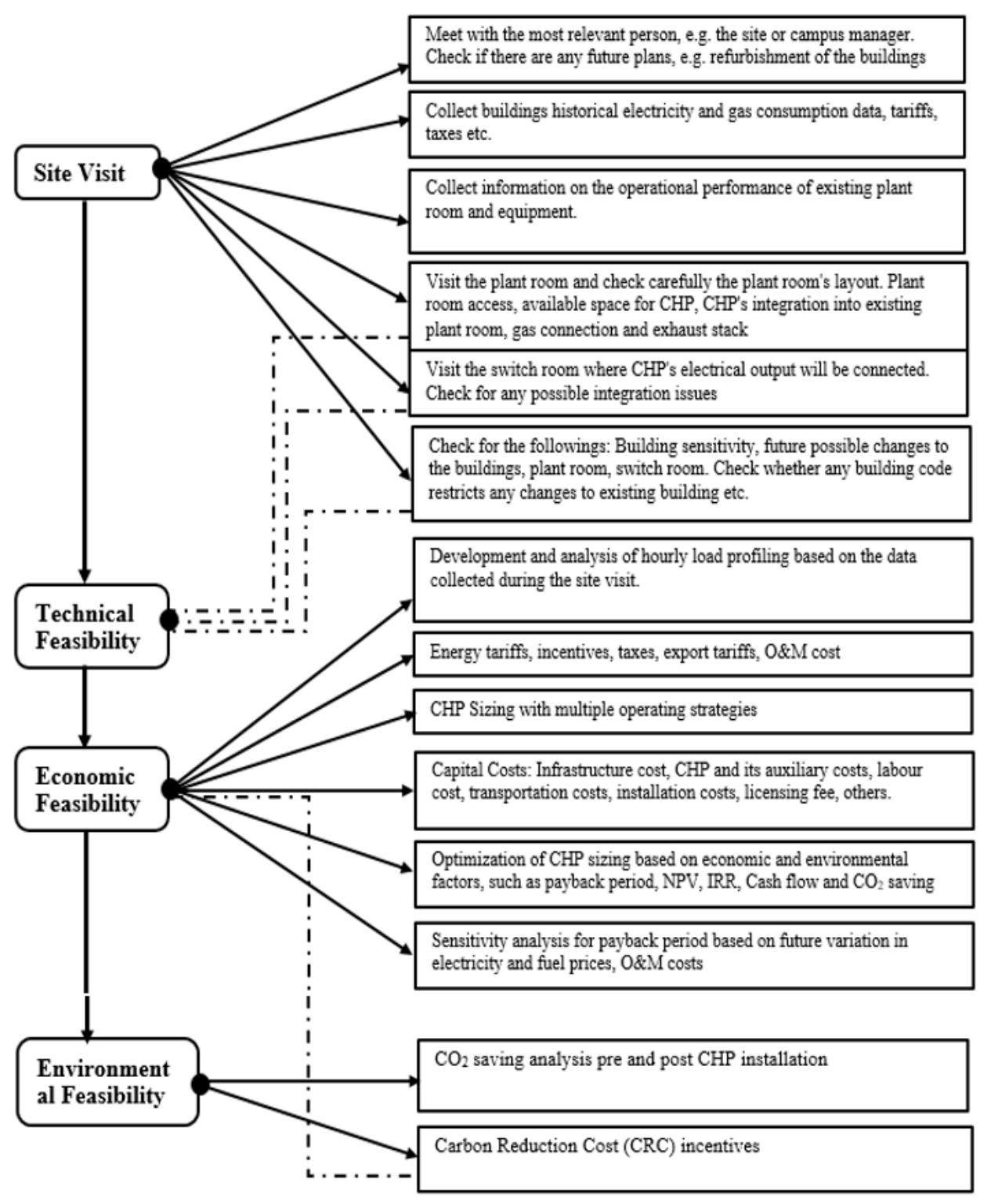

Figure 4. Methodology of the case study.

First step is the site visit. A comprehensive site visit could be helpful in the collection of the required energy consumption data, information about different buildings, plant rooms, and switch rooms. Secondly, the site visit could help in understanding any possible future changes to the buildings, any site constraints that could affect the technical and economic feasibility of CHP. Different factors such as very high sensitive building or asbestos in the building fabric etc. may not allow the shutdown of the building's supply for even a shorter period of time, thus not allowing CHP installation. Other factors, such as unavailability of space for $\mathrm{CHP}$ inside the plant room, difficult access for $\mathrm{CHP}$ connection to the plant room, under rated capacity of existing gas connection, longer distance between CHP, and buildings' switch room could cause additional infrastructure costs that would lead to a higher 
capital cost of the project and could adversely affect the economic feasibility of the CHP. It is, therefore, desired that all such factors and their associated financial effect must be investigated during the site visit.

\subsection{Site Details-The University Campus}

The site to be investigated for the CHP's feasibility is the Charterhouse Square Campus of the Queen Mary University of London (QMUL). With nearly 17,140 students and 4000 staff, QMUL is a member of the Russell Group of leading British research universities. The University's Carbon Management and Implementation Plan was approved by Council in April 2011 and identified that the baseline carbon emissions (2005/6) were $24,255 \mathrm{t} / \mathrm{CO}_{2}$. Because of its charity status, QMUL is exempted from the Climate Change Levy (CCL) tax on its utilities.

\subsection{Site Visit and Technical Feasibility of CHP}

During the site visit of the campus, data and information were collected from the office of the site manager. Plant rooms and switch rooms of the buildings were visited and the necessary notes were made. The site manager was interviewed about the possible opportunity of a CHP plant inside the existing plant room. The Charterhouse Square campus of QMUL is situated in London and it is shown in Figure 5.

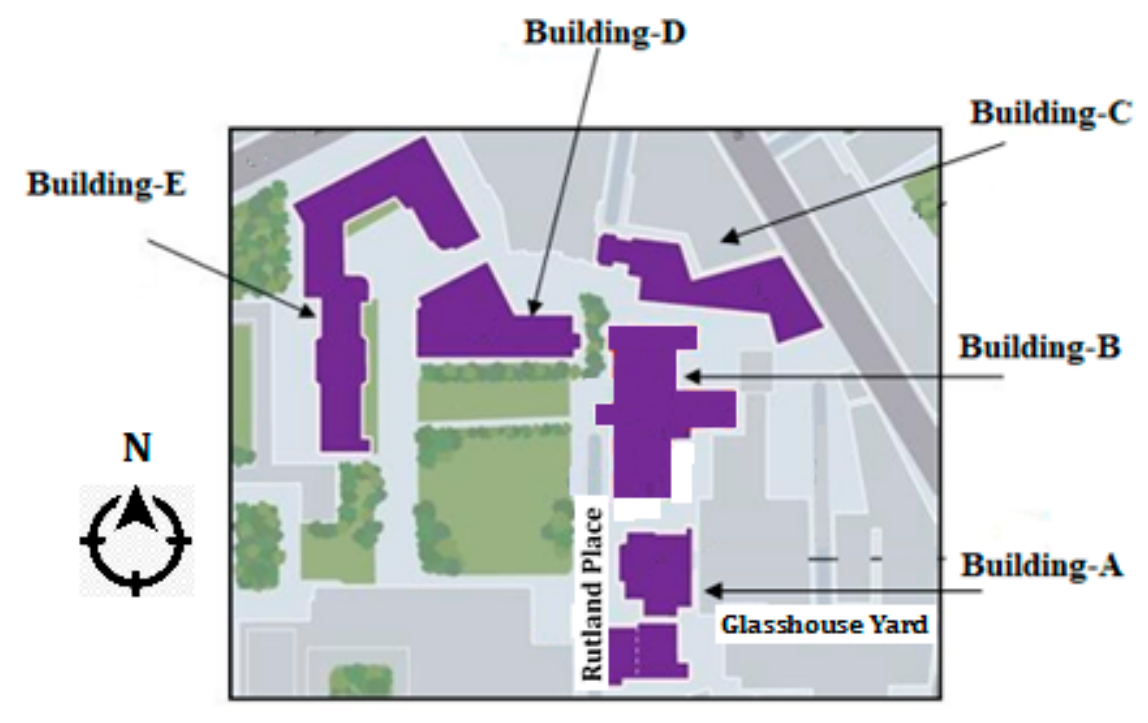

Figure 5. The Charterhouse Campus.

The campus mainly includes one student accommodation (Building-B) and four research oriented buildings, i.e., (Buildings-A, C, D and E). Buildings sensitivity was discussed with the site manager who confirmed that buildings have resilience to allow for the installation of a CHP plant.

Building-B is a student residence hall with 209 single rooms. The central plant room is located in the basement of this building and it provides heating and hot water to buildings $\mathrm{B}, \mathrm{D}$ and $\mathrm{E}$ via a mini district heating scheme. Supply and return hot water pipes run through a tunnel between Building-B and Building-E. Table 2 shows the life and the area of these buildings. It is obvious that buildings $\mathrm{A}$, $B$ and $E$ are very old with age $>50$ years, whereas buildings $C$ and $D$ are relatively new. Area wise, buildings $\mathrm{B}$ and $\mathrm{E}$ are the major buildings in the campus. 
Table 2. Details the life, type, and area of the different campus buildings.

\begin{tabular}{cccc}
\hline Charterhouse Square & Life & Type of Building & Area, $\mathbf{~ m}^{\mathbf{2}}$ \\
\hline Building-B & $1935-1964$ & Student Accommodation & 8266 \\
Building-E & 1963 & Research Building (Labs \& Offices) & 11,459 \\
Building-D & 1991 & Research Building (Labs \& Offices) & 2042 \\
Building-C & 2010 & Research Building & 3200 \\
Building-A & $1894-1935$ & Offices \& Research Building & 2590 \\
\hline
\end{tabular}

\subsubsection{Plant Room Details and Layout}

The plant room is situated in the basement on the east end of the Building-B. The details of different plant equipment are given in Table 3.

Table 3. Details of plant room and equipment.

\begin{tabular}{ll}
\hline \multicolumn{1}{c}{ Equipment/Item } & \multicolumn{1}{c}{ Technical Details } \\
\hline Boilers & $\begin{array}{l}\text { Quantity: } 3 \times 1500 \mathrm{~kW}+1 \times 450 \mathrm{~kW}=4950 \mathrm{~kW} . \\
\text { Manufacturer: Wellman Robey Ygnette, Installation in: } \\
\text { 1996. Boiler number 2 has maintenance issues. }\end{array}$ \\
\hline Gas meter & $\begin{array}{l}\text { Rotary type medium pressure gas meter, maximum } \\
\text { capacity of } 16,000 \text { CFT i.e., } 4.95 \mathrm{MW} .\end{array}$ \\
\hline Main gas pipe & Diameter (Ø): $150 \mathrm{~mm}$ \\
\hline Gas connection inside plant room & $\begin{array}{l}\text { For boilers 1, 2 and } 3 \text { gas connections of diameter }(\varnothing) 75 \\
\text { mm each connected to a gas booster. Boiler } 4 \text { has a gas } \\
\text { connection of diameter (Ø) } 50 \mathrm{~mm} .\end{array}$ \\
\hline Return \& Flow Headers & Diameter (Ø): $150 \mathrm{~mm}$ \\
\hline Balancing Vessel & Dimensions: $2000 \mathrm{~mm} \times 900 \mathrm{~mm}$ \\
\hline Building Management System (BMS) & TAC Vista, Schneider Electric \\
\hline Exhaust Stack-1 & Diameter (Ø): $460 \mathrm{~mm}$. \\
\hline Exhaust Stack-2 & Diameter $(\varnothing): 350 \mathrm{~mm}$. \\
\hline Plant room & Location: Basement, area, $178 \mathrm{~m}{ }^{2}$. Ceiling height: $4200 \mathrm{~mm}$ \\
\hline
\end{tabular}

\subsubsection{Installation of CHP Inside Plant Room}

At current, there are four boilers altogether that can deliver $4900 \mathrm{kWth}$ of thermal supply at any time. Analysis of hourly thermal demand profile will demonstrate whether this plant is over-sized or not. The site manager confirmed that he has never witnessed three boilers running together, and that the plant is oversized. Maintenance issues have been reported with boiler number 2, and its tubes have been inspected recently. Boiler number 1, 2 and 3 share a single flue stack, whereas boiler number 4 has its own dedicated flue stack. The gas meter serving the plant room has a maximum capacity of 4.95 MW and could easily meet the requirements of a CHP plant. It was observed that there is no free space available inside the plant room for any additional equipment or for any maintenance purpose. However, if one or two boilers are removed, there will be adequate space for a CHP plant. This would certainly involve additional cost. There are a number of advantages of installing $\mathrm{CHP}$ in place of boiler number 4 . These include:

(a) no planning permission will be required;

(b) easy thermal connection to return header;

(c) low infrastructure cost;

(d) no separate gas connection is required;

(e) easy BMS connection with CHP plant;

(f) no noise to the neighboring residential flats; and,

(g) no visual impact. 


\subsubsection{Thermal Connection of CHP with the Existing Infrastructure}

$\mathrm{CHP}$ could be installed inside the plant room provided at least one boiler, i.e., boiler number 4 is removed. Thermal output of the CHP will be connected to the return header. CHP will act as a lead boiler and will meet the maximum thermal demands of the connected buildings.

\subsubsection{Electrical Connection of $\mathrm{CHP}$ with the Existing Infrastructure}

Ideally, CHP should be connected to a switch room where electricity demand is maximum when compared to other buildings. Building-B's switch room is very old and there are plans to upgrade it in future. Further, its electricity demand is less than building-E, which offers an opportunity for CHP's electrical connection. However, the switch room of building-E located in its basement is about $200 \mathrm{~m}$ away from the central plant room, i.e., CHP's proposed place of installation. This will add the electrical cabling cost. Compliance to the Government's regulation G59 will be ensured for a safe connection. G59 is a regulation that is in place to ensure the safe connection of generator devices that run in parallel with grid electricity. This regulation ensures that no CHP can be connected in parallel to the national grid without the knowledge and permission of the local electricity authority, and it will disconnect from the grid in the case of any power cut to ensure safety [18].

Through the multiple site visits, it was found there exists no serious threat to the installation of a CHP in the campus. This confirmed the technical viability of the CHP plant.

\subsection{Analysis of Energy Consumption Data}

The data collected during site visit was critically analysed. It was found that the Charterhouse Square campus currently consumes $18 \%$ of the total annual energy consumption of the QMUL and emits $4900 \mathrm{t} / \mathrm{CO}_{2}$ per year. Data was transformed into hourly electricity and thermal profiles as for a reliable feasibility of a CHP plant, it is very important to have real hourly electricity and thermal demand profiles. Use of estimated hourly profiles might lead to an under-sized or over-sized CHP plant [19].

\subsubsection{Thermal Demand Profile}

In 2010, the existing boiler plant room of Building-B consumed 4.19 GWh of gas. This plant supplies heating and hot water to buildings $B, D$, and $E$ through a mini district heating scheme, and therefore, thermal demand profile is an aggregated profile of buildings B, D and E. Hourly thermal demand profiles were developed using the hourly gas consumption data considering a boiler efficiency of $78 \%$. Figure 6 shows hourly thermal demand profiles for four seasons, i.e., winter, spring, summer, and autumn. It is apparent that the thermal demand is higher during the winter due to higher heating and hot water demands, and it is lower in the summer as there is only hot water demand. The profiles further suggest that peak thermal demand occurs at 4:00 a.m. when the boilers are started via the Building Management System (BMS). Base thermal demand during the night remains at above $400 \mathrm{~kW}$ in winter and drops to $180 \mathrm{~kW}$ during summer. The maximum thermal demand at any time during the whole year never goes beyond $675 \mathrm{kWth}$. This fact is further confirmed by looking at the thermal load duration curve, as shown in Figure 7. 


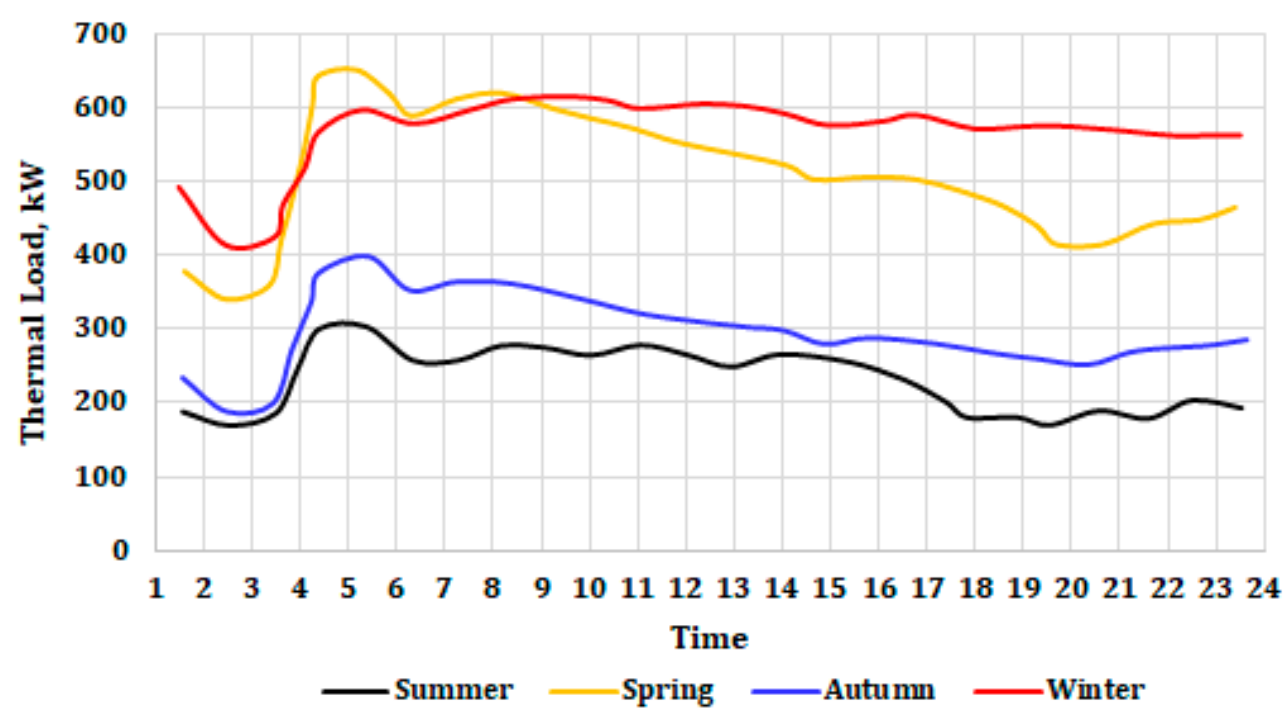

Figure 6. Thermal demand profile.

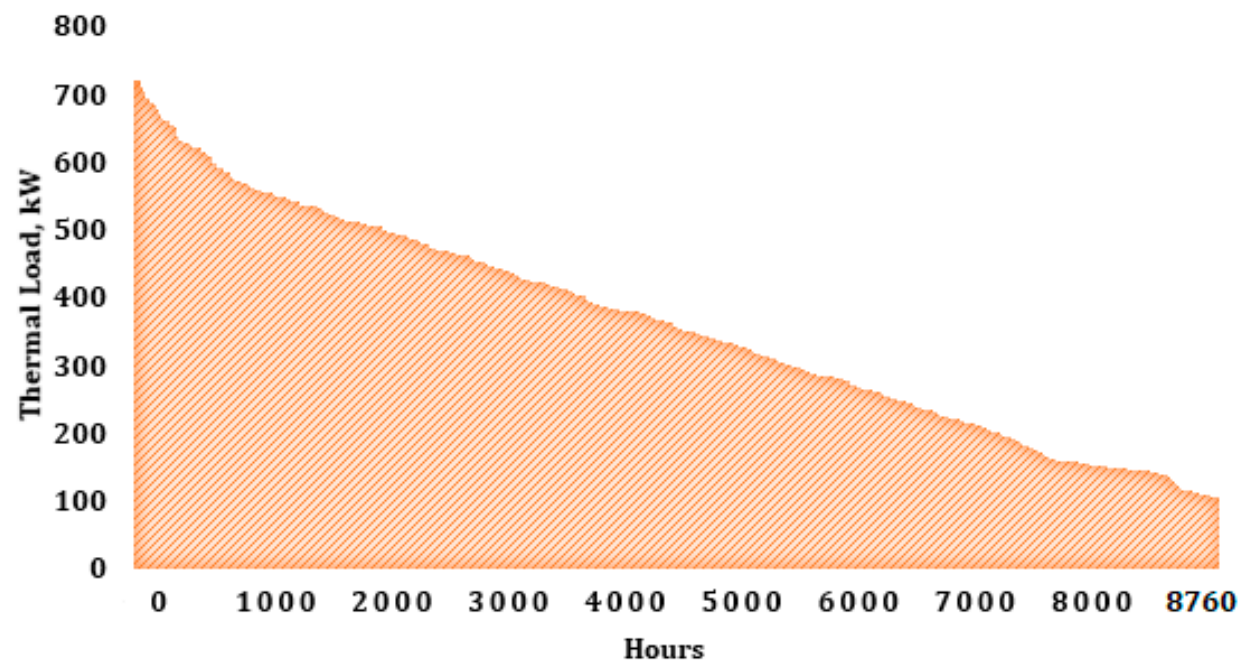

Figure 7. Thermal Load duration Curve.

This clearly demonstrates that this boiler plant is massively over-sized, being almost six times greater than the required size. The profiles further suggest that only one boiler of $1500 \mathrm{~kW}$ can easily meet the whole thermal demand of these buildings. This finding was discussed with the site manager who confirmed that he has never seen all of the boilers running together.

This analysis of hourly thermal profiles confirms that there is a strong opportunity to remove boiler number 3 and 4 to provide space for an optimum sized CHP plant. The removal of these two boilers will provide space for a CHP plant and space that is required for its maintenance. With the remaining two boilers, the plant room will have sufficient resilience and capacity to meet the thermal demands of the buildings. Further analysis for CHP feasibility has been done by considering that the CHP plant will be installed inside the plant room in place of boiler number 4 , whereas the area that is covered by boiler 3 will be used for maintenance purpose.

\subsubsection{Electricity Demand Profile}

As CHP's electrical output can be connected only to a single Low Voltage (LV) supply, it is therefore, recommended to connect $\mathrm{CHP}$ with the building having highest electricity consumption. This way a bigger CHP could be sized for higher financial savings. In our case, Building-E has the 
highest electricity consumption demand, and therefore, electricity consumption demand profile of this building has been considered for the CHP's connection. The LV switch room of Building-E is located in the building's basement, and it is $200 \mathrm{~m}$ from the main plant room in Building-B. The annual electricity consumption through this switch room is $3 \mathrm{GWh}$, i.e., nearly double to the electricity consumption at Building-B switch room. The electricity consumption data of the Building-E electricity meter was critically analyzed and was converted into hourly profiles. Figure 8 shows the hourly demand profile of this building for four different seasons.

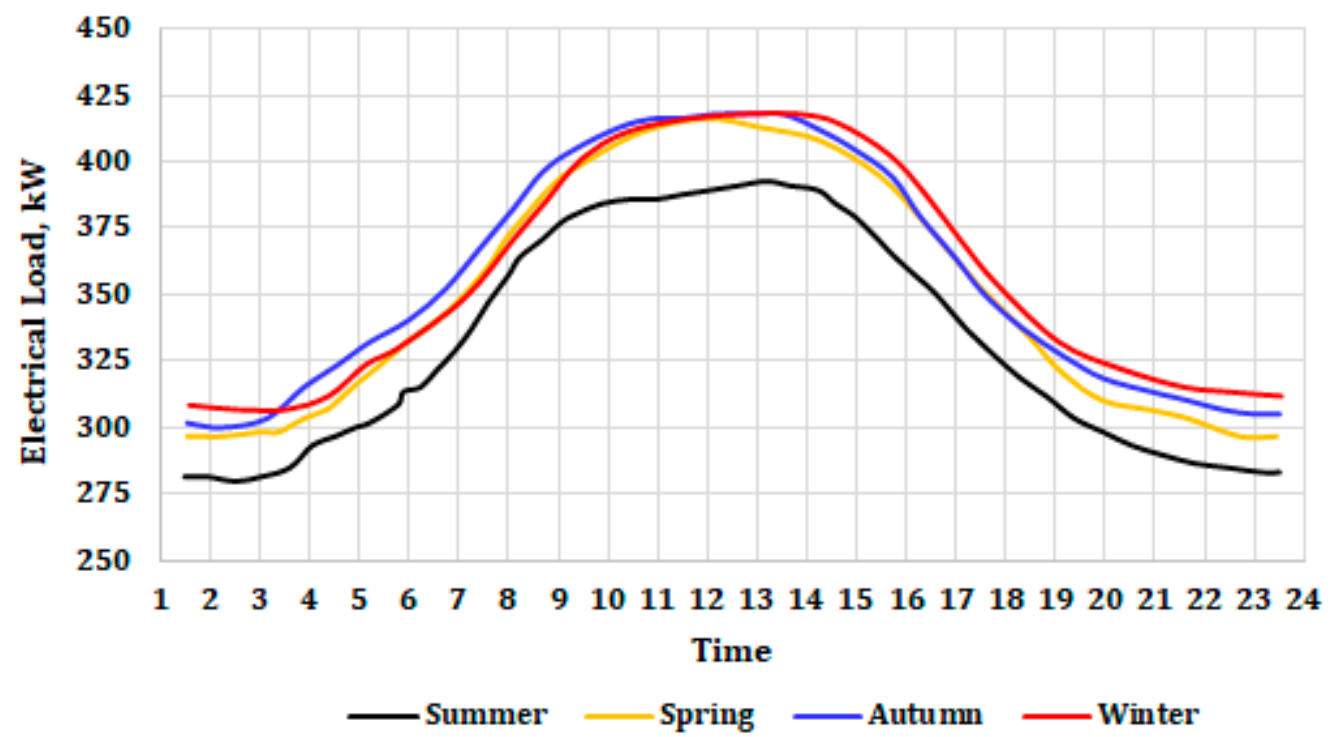

Figure 8. Electricity demand profile.

Figure 8 demonstrates that the electricity demand starts increasing at 4:00 a.m. when BMS kicks on the boilers. Electrical load further increases when the buildings open at 7:00 a.m. With the arrival of staff and students, load further increases and reaches to peak load demand at 9:00 a.m. due to lighting and IT equipment coming online. It then remains constant until 2:00 p.m. Load demand starts decreasing at 2:00 p.m. until the buildings are closed at 10:00 p.m. The base load over the night period remains constant until 4:00 a.m. This is mainly because of the lighting, air handling units, and extract fans running during this period. At any time in the year, the base electrical load remains above $275 \mathrm{~kW}$. This is further confirmed by looking at the electrical load duration curve, as shown in Figure 9.

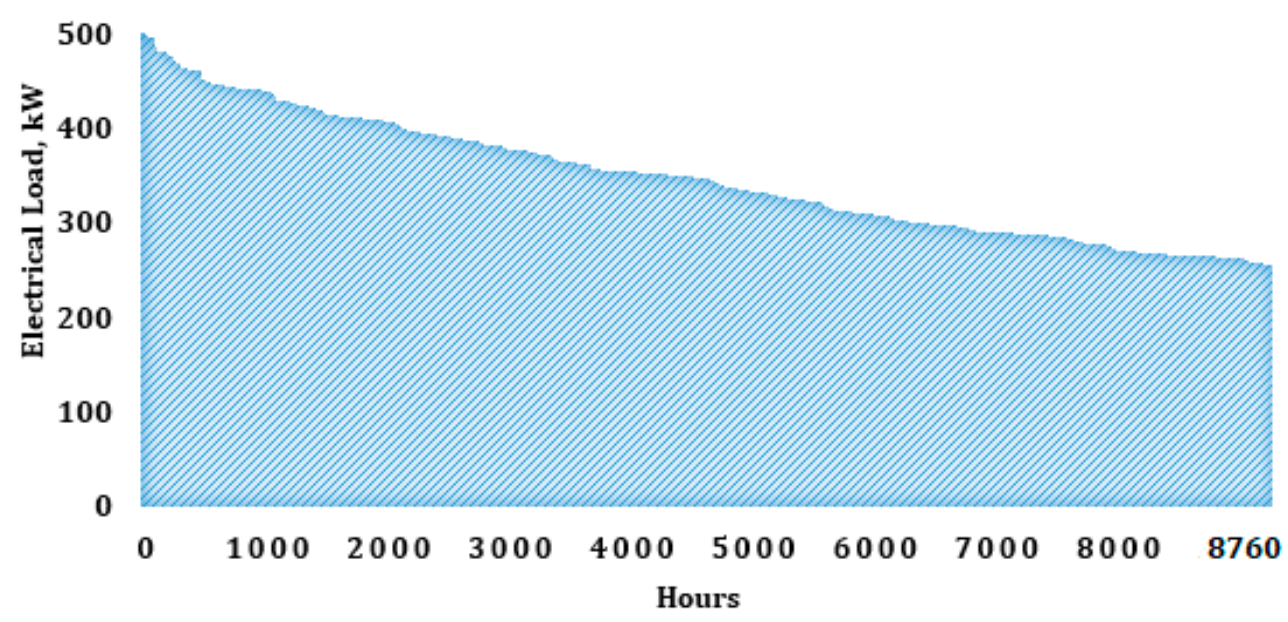

Figure 9. Electrical Load duration Curve. 


\subsection{Economic Feasibility of $\mathrm{CHP}$}

First task towards the economic feasibility of a CHP project is the calculation of the optimum size of a CHP plant for the campus.

\subsubsection{CHP Sizing}

CHP sizing is the main critical component of the economic feasibility study. Ideally, the CHP plant should be sized to operate at maximum continuous rating for a minimum of $5000 \mathrm{~h}$ per year in order to maximize return on investment, and maximize the carbon dioxide emission benefits [20]. CHP sizing is generally performed using a computer-based CHP sizing model. Such a tool needs to be easy to use, but with a full range of characteristics. A model with limited features could result in an under sized or oversized CHP scheme that could lead to a complete failure of the project. For the purpose of this study, we have used the London South Bank University (LSBU) CHP model that was developed by Amber, 2013 as a part of his PhD thesis. The development of the model is fully described in Amber (2013) [21,22]. It is a spreadsheet-based model developed in Microsoft Excel ${ }^{\circledR}$. Its prime features include its simplicity and ability to model CHP for a single or multiple buildings. User can select a CHP plant size (kWe) to see the technical, financial, and environmental results. The model automatically generates a comparison table for different sizes of CHP plants in terms of capital investment, net savings, payback period, Net Present Value (NPV), Internal Rate of Return (IRR), annual running hours, and $\mathrm{CO}_{2}$ emissions savings [22]. This approach makes it very easier for the user to identify and pick up the optimum size of the CHP plant. For finding the optimum size of the CHP, hourly profiles were fed into the LSBU CHP model.

\subsubsection{Results of CHP Sizing Exercise}

The LSBU model results show that an electricity led gas fired reciprocating engine type CHP of $230 \mathrm{~kW}$ electrical output with $304 \mathrm{~kW}$ thermal output is an optimum size for this campus. The parasitic load of this CHP is $13 \mathrm{~kW}$ which means it will only deliver $215 \mathrm{~kW}$ of electricity when running at full load. Electrical efficiency at $100 \%, 75 \%$ and $50 \%$ load are $32 \%, 30 \%$ and $29 \%$, respectively, whereas thermal efficiency at $100 \%, 75 \%$ and $50 \%$ are $42 \%, 44 \%$ and $49 \%$, respectively. CHP will modulate according to the electricity demand of the building and will generate $1412 \mathrm{MWh}$ of electricity and $1944 \mathrm{MWh}$ of useable heat. It will save $£ 51 \mathrm{k}$ per year and it will result in a $\mathrm{CO}_{2}$ emissions reduction of $395 \mathrm{t} / \mathrm{CO}_{2}$.

Figure 10 presents the monthly variation in the gas consumption before and after the installation of $230 \mathrm{~kW} \mathrm{CHP.}$

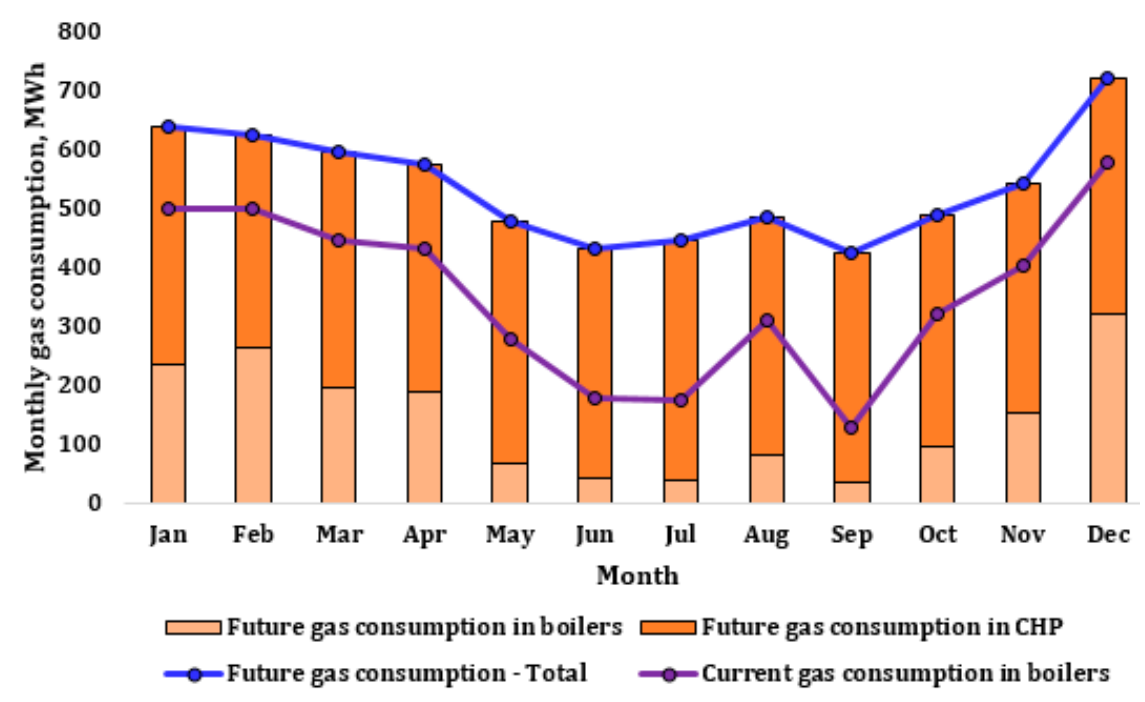

Figure 10. Gas consumption before and after CHP plant installation. 
It is apparent that the site's annual gas consumption will increase by $53 \%$. This increase in the gas consumption is due to the fact that the CHP plant will be running as the lead boiler and it will consume $75 \%$ of the future annual gas consumption, whereas boilers will consume only $25 \%$, as shown in Figure 10. The CHP plant will run as lead boiler and it will meet a higher proportion of the thermal demand of campus buildings. Boilers 1 and 2 will run to only top up supply to the buildings. In terms of thermal demand, the model results show that there will be some excess heat from the CHP plant during the summer months, as the demand during summer drops lower than CHP thermal output, as shown in Figure 11.

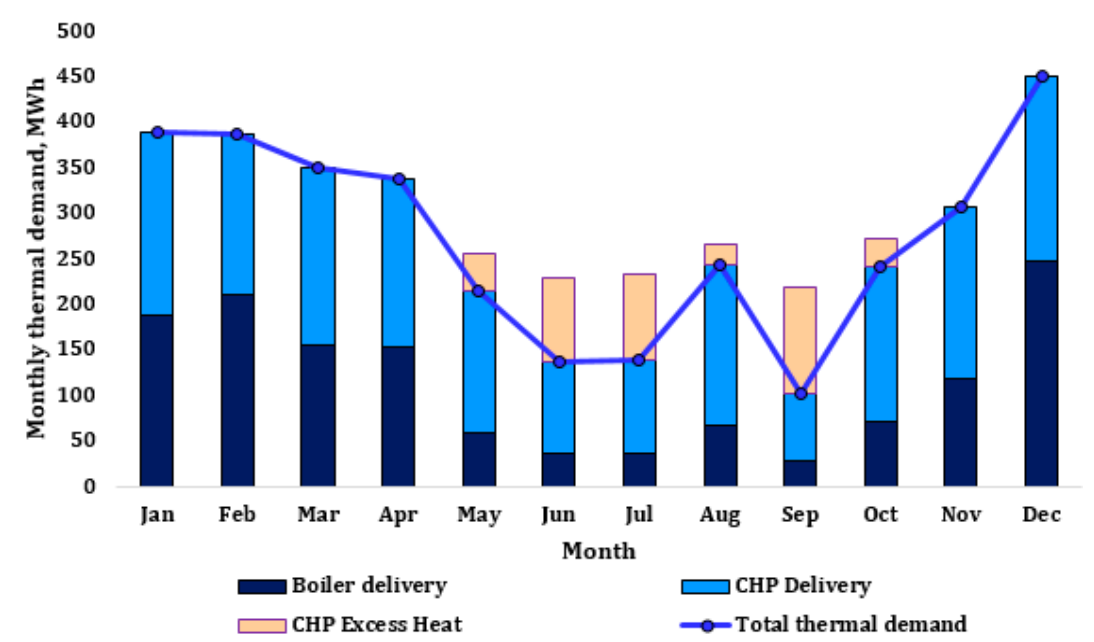

Figure 11. Thermal demand before and after CHP plant installation.

This excess heat could be used for a heat-driven absorption chilling plant that will extend the base load heat demand into the summer months, and thus will increase the running hours of CHP during these months. Absorption chillers use far less electricity than the conventional equivalents and avoid the use of greenhouse or ozone depleting gases. In terms of its electricity generation, the CHP plant will meet $47 \%$ of the Building-E's switch room electricity demand. The CHP plant will not generate any excess electricity and it will modulate in the case that the demand goes below the maximum electrical output. Electricity demand profile that is shown earlier in Figure 8 suggests that a CHP of size less than the base electrical load (i.e., $275 \mathrm{~kW}$ ) will run $24 / 7$ at full load, as its electrical capacity is less than the base load. Grid reliance will be reduced by $47 \%$, resulting in an annual saving of $£ 111 \mathrm{k}$ in electricity costs. Monthly electricity generation contribution of CHP is shown in Figure 12.

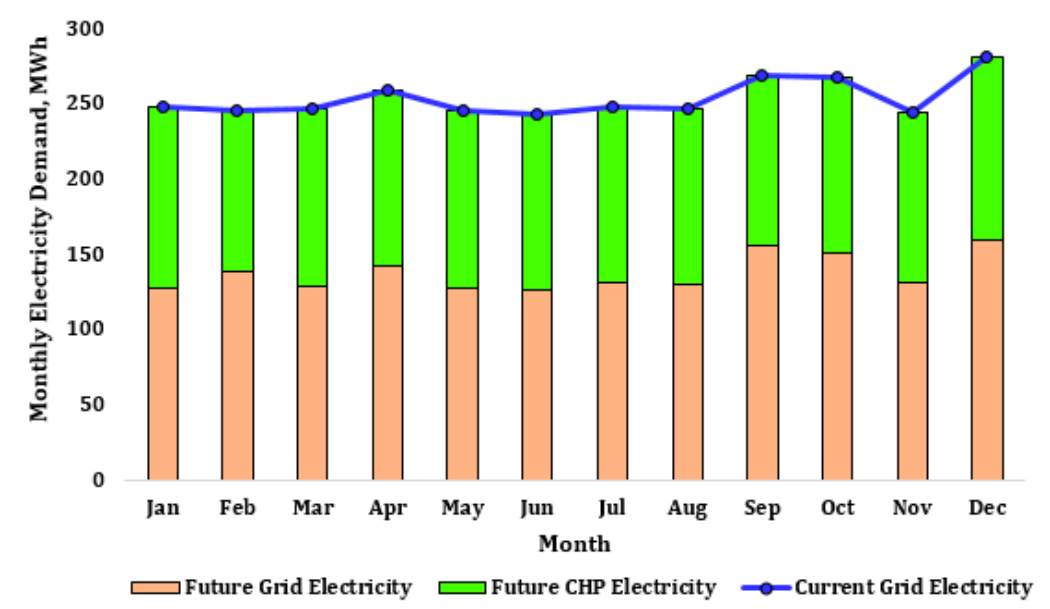

Figure 12. Electricity consumption before and after CHP plant installation. 


\subsubsection{Environmental Savings}

In terms of environmental savings, the $\mathrm{CHP}$ model calculates hourly $\mathrm{CO}_{2}$ emissions using a carbon factor $0.541 \mathrm{~kg} / \mathrm{kWh}$ for electricity and $0.194 \mathrm{~kg} / \mathrm{kWh}$ for natural gas. The results show that installation of $230 \mathrm{~kW} \mathrm{CHP}$ will save 395 tonnes of $\mathrm{CO}_{2}$ for this University campus, which is a $16 \%$ reduction in current emissions level.

\subsubsection{Economic Feasibility Parameters}

For performing the economic viability of CHP, the following inputs were fed to the LSBU CHP model, as shown in Table 4.

Table 4. Values of input parameters for the London South Bank University (LSBU) CHP model.

\begin{tabular}{ccc}
\hline Parameter & Value/Unit & Source \\
\hline Electricity day tariff & $7.875 \mathrm{p} / \mathrm{kWh}$ & Electricity bills \\
Electricity night tariff & $4.801 \mathrm{p} / \mathrm{kWh}$ & Electricity bills \\
Electricity fixed charges & $£ 12,000 / \mathrm{year}$ & Electricity bills \\
Natural gas tariff & $2.375 \mathrm{p} / \mathrm{kWh}$ & Gas bills \\
Boiler's efficiency & $78 \%$ & Interview with the site manager \\
VAT charge & $@ 20 \%$ & Electricity and gas bills \\
CRC cost & $£ 12 / \mathrm{t} / \mathrm{CO}_{2}$ & {$[21]$} \\
$\mathrm{CO}_{2}$ emission factor for electricity & $0.541 \mathrm{~kg} / \mathrm{kWh}$ & {$[21]$} \\
$\mathrm{CO}_{2}$ emission factor for natural gas & $0.194 \mathrm{~kg} / \mathrm{kWh}$ & {$[21]$} \\
Capital cost & $£ 403,000$ & ENER-G \\
O\&M cost per kWh & $£ 0.01 / \mathrm{kWh}$ & ENER-G \\
Weighted average cost of capital (WACC) & $5 \%$ & ENER-G \\
Annual inflation rate & $5 \%$ & ENER-G \\
Project Life & 10 years & ENER-G \\
\hline
\end{tabular}

\subsubsection{Capital Cost Analysis}

The capital cost of a CHP project is a crucial factor and it plays a vital role in the project's economics. It is of great importance that the capital cost should include all of the possible costs that the project will incur. For a good estimate of capital cost (CC), meetings were arranged with one of the leading CHP supplier. After multiple visits of the site along with their engineer, a final estimate of the capital cost of the project was made which was $£ 403,000$, including Value-Added Tax (VAT) charges. The breakdown of this estimate is shown in Figure 13. It could be seen that installation and commissioning cost has a second highest share (35\%) after the CHP cost, i.e., 37\%. This higher installation cost includes all of the modifications to be made in the plant room and switch room. For example, removal of two boilers from the plant room was recommended and this certainly added cost. 


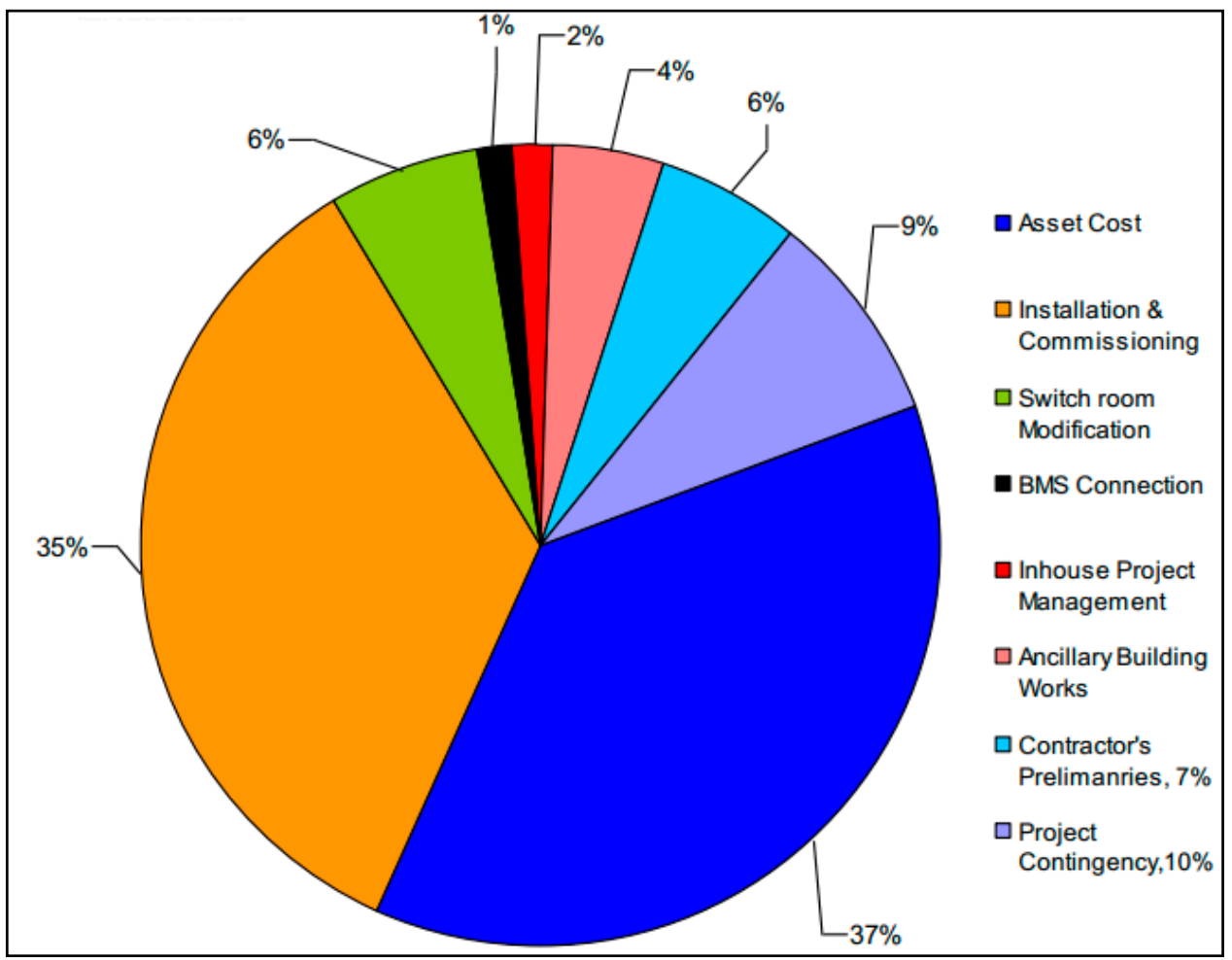

Figure 13. Breakdown of the capital cost.

\subsubsection{Results of Economic Feasibility}

Table 5 presents the results of the economic feasibility of the $230 \mathrm{~kW} \mathrm{CHP}$ for the Charterhouse Square campus of QMUL. It is apparent that the installation of a $230 \mathrm{~kW} \mathrm{CHP} \mathrm{at} \mathrm{the} \mathrm{Charterhouse}$ Square campus of QMUL will result in a gross and net savings of $£ 66,057$ and $£ 51 \mathrm{k}$, respectively. With the current electricity and gas tariffs, the payback period is 7.86 years.

Table 5. Results of economic feasibility.

\begin{tabular}{cccc}
\hline Quantifiable Financial Benefit & Current (without CHP) & Future (with CHP) & Savings \\
\hline Electricity Cost (Current Tariffs) & $£ 230,473$ & $£ 119,234$ & $£ 111,239$ \\
Gas Cost (Current Tariff) & $£ 99,720$ & $£ 152,564$ & $-£ 52,844$ \\
Net Energy Cost Saving & $£ 330,193$ & $£ 271,798$ & $£ 58,395$ \\
VAT on electricity cost (5\%) & $£ 10,924$ & $£ 5362$ & $£ 5562$ \\
VAT on gas cost (5\%) & $£ 4986$ & $£ 7628$ & $-£ 2642$ \\
Net VAT Savings & $£ 15,910$ & $£ 12,990$ & $£ 2920$ \\
CRC Charges@ $£ 12 / \mathrm{t} / \mathrm{CO}_{2}$ & $£ 29,062$ & $£ 24,320$ & $£ 4742$ \\
Gross Savings & - & - & $£ 66,057$ \\
O \& M Cost & - & $£ 14,744$ & $-£ 14,744$ \\
Net Savings & - & - & $£ 51,313$ \\
\hline & Payback period & 7.86 years \\
& Internal Rate of Return (IRR) & $9 \%$ \\
Net Present Value (NPV) & & $£ 82,000$ \\
\hline
\end{tabular}

The Net Present Value (NPV) and the Internal Rate of Return (IRR) for this project have been calculated with a weighted average cost of capital (WACC) of $5 \%$ and a project life of 10 years-the recommended expected lifespan of this size of the CHP plant. The NPV is calculated to be close to $£ 82 \mathrm{k}$ and the IRR is estimated at $9 \%$. 
The results of economic feasibility clearly suggest that the installation of a $230 \mathrm{~kW} \mathrm{CHP} \mathrm{is}$ an economical option for the campus, which will not only reduce the grid dependence but will increase the reliability of energy supply and will generate financial and environmental savings.

\subsubsection{Sensitivity Analysis of Payback Period}

Financial risk is considered as one of the main barriers for investing in energy-efficient technologies [23]. One of such possible risk is uncertainties of electricity and gas prices [24]. Wickart and Madlener [25] found that, under higher price volatility levels, a CHP system offers more profit than a conventional generation plant. Spark gap, which is the difference between electricity and gas price, is therefore an important factor for the economics of the CHP plant. The LSBU CHP model automatically performs a sensitivity analysis for the payback period of the CHP project with different variations in the electricity and gas prices (range: $-10 \%$ to $+30 \%$ ) in order to check the economic feasibility of CHP. Figure 14 shows the sensitivity analysis for the optimum sized CHP, i.e., $230 \mathrm{~kW}$.

$X$-axis shows the variation in gas price, $Y$-axis shows the payback period, whereas the variation in electricity price is shown by different bars, e.g., green bar represents $+30 \%$ variation in the electricity price. It is apparent that with the current prices, the payback period is 7.86 years.

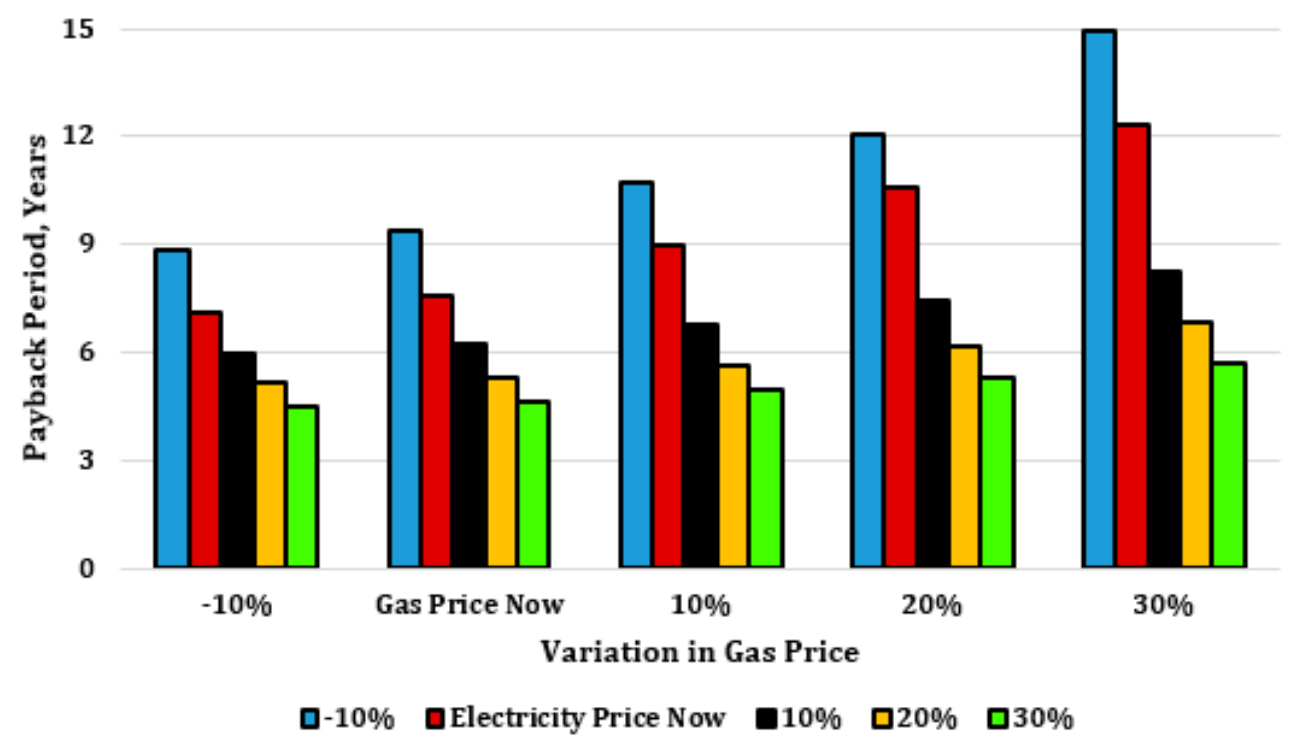

Figure 14. Sensitivity analysis of payback period.

The sensitivity analysis shows that if electricity price and gas price increase by $30 \%$ and $20 \%$ respectively, the payback period of this CHP project will become 5.7 years. This means as long as electricity price increases, the economics of $\mathrm{CHP}$ project will become better and better.

\section{Conclusions}

Techno, economic, and environmental feasibility of a CHP scheme for a university campus located in London was performed using real datasets and information that were collected through site visits and interviews with the site manager. CHP sizing was performed using the LSBU CHP model, which is capable of performing economic and environmental feasibility of $\mathrm{CHP}$ for a single or multiple buildings. The model results showed that a CHP of $230 \mathrm{~kW}$ size is the optimum size for this campus, which will generate an annual financial savings of $£ 51 \mathrm{k}$ with a payback period of 7.86 years and an IRR of $9 \%$. The model further show that installation of this CHP will result in save $395 \mathrm{t} / \mathrm{CO}_{2}$ on an annual basis. The results demonstrated that the CHP is economically and environmentally feasible for this site.

The following are the conclusions of this study. 
- Installation of an electricity led $230 \mathrm{~kW}$ CHP will result in a financial savings of $£ 51 \mathrm{k}$ and environmental savings of $395 \mathrm{t} / \mathrm{CO}_{2}$ on an annual basis. The project payback period and II as per current energy tariffs are 7.86 years and $9 \%$, respectively.

- Optimum CHP sizing is crucial for the reliable economic and environmental feasibility of CHP, and it must be performed using a validated model.

- Use of estimated energy profiles could result in an under-sized or over-sized CHP scheme that could lead to a complete failure of the project.

- Economic feasibility barriers mainly comprised of a higher infrastructure cost and lower/narrow spark gap.

- Factors such as difficult plant room access, non-availability of space inside the plant room, complex mechanical and electrical connection of CHP to the existing infrastructure, non-availability of gas connection, and exhaust stack installation can increase the infrastructure cost by a big margin, leading to a higher capital cost of the project.

- Spark gap plays a vital role in the economic feasibility of CHP. A wider spark gap will lead to higher financial savings and vice versa. Sensitivity analysis shows that future variation in spark gap could affect the project's economics positively if spark gap increases and vice versa.

- Future changes to the building fabric, plant room or switch room, and equipment efficiency may result in lower electrical and thermal demands, which will affect the CHP's output.

- It was also identified that CHP's electrical output cannot be connected to more than one LV supply because of system complexities. Therefore, it is recommended that CHP's electrical output should be connected to the LV supplies that have consistent and higher electrical load. This helps in sizing a big CHP size that would then offset higher amount of grid electricity and will thus result in higher financial savings.

Author Contributions: K.P.A. conceived the idea and performed the analysis. T.D. and N.I.R. contributed in the write up of the manuscript and also gave useful insights during the data analysis. A.K.K. and R.A. prepared the relevant graphics and tables and contributed in the writing of description of these graphics and tables.

Acknowledgments: Authors would like to thank Rebecca Maiden, Head of Sustainability at Queen Mary University of London for arranging our visits to their campus buildings and particularly for providing us their energy consumption data. We would also like to thank Mark Kelly (Project development Engineer, ENERG) for providing technical and operational performance data of their UK CHP installations and for guiding us on the capital cost calculations.

Conflicts of Interest: The authors declare no conflict of interest.

\section{Abbreviations}

$\begin{array}{ll}\text { BMS } & \text { Building Management System } \\ \text { CCL } & \text { Climate Change Levy } \\ \text { CHP } & \text { Combined Heat and Power } \\ \text { CHPA } & \text { Combined Heat and Power Association } \\ \text { CHPQA } & \text { Combined Heat and Power Quality Assurance } \\ \text { CIBSE } & \text { Chartered Institute of Building Services Engineers } \\ \text { CRC } & \text { Carbon Reduction Commitment } \\ \text { HE } & \text { Higher Education } \\ \text { HEI } & \text { Higher Education Institutions } \\ \text { HEFCE } & \text { Higher Education Funding Council for England } \\ \text { HESA } & \text { Higher Education Statistics Agency } \\ \text { HMRC } & \text { HM Revenue and Customs } \\ \text { IRR } & \text { Internal Rate of Return } \\ \text { kW } & \text { Kilowatt } \\ \text { kWe } & \text { Kilowatt Electric } \\ \text { kWh } & \text { Kilowatt hour } \\ \text { kWth } & \text { Kilowatt Thermal }\end{array}$




$\begin{array}{ll}\text { LSBU } & \text { London South Bank University } \\ \text { NPV } & \text { Net Present Value } \\ \text { O \& M } & \text { Operations and Maintenance } \\ \text { QMUL } & \text { Queen Mary University of London } \\ \text { UK } & \text { United Kingdom } \\ \text { WACC } & \text { Weighted Average Cost of Capital }\end{array}$

\section{References}

1. Robinson, O.J.; Tewkesbury, A.; Kemp, S.; Williams, I.D. Towards a universal carbon footprint standard: A case study of carbon management at universities. J. Clean. Prod. 2018, 172, 4435-4455. [CrossRef]

2. UK Universities. 2015. Available online: http:/ / www.universitiesuk.ac.uk/ (accessed on 12 June 2016).

3. Ward, I.; Ogbonna, A.; Altan, H. Sector review of UK higher education energy consumption. Energy Policy 2008, 36, 2939-2949. [CrossRef]

4. Higher Education Funding Council for England (HEFCE). Carbon Reduction Target and Strategy for Higher Education in England. Available online: http:/ /www.hefce.ac.uk/pubs/year/2010/201001/ (accessed on 11 September 2012).

5. Warner, K. Energy Renewals. UK Universities Struggle to Meet Emissions Targets. Available online: https:/ / www.energyrenewals.co.uk/uk-universities-struggle-meet-emissions-targets/ (accessed on 23 November 2016).

6. Amber, K.P.; Aslam, M.W.; Mahmood, A.; Kousar, A.; Younis, M.Y.; Akbar, B.; Chaudhary, G.Q.; Hussain, S.K. Energy Consumption Forecasting for University Sector Buildings. Energies 2017, 10, 1579. [CrossRef]

7. Raine, R.D.; Sharifi, V.N.; Swithenbank, J. Optimisation of combined heat and power production for buildings using heat storage. Energy Convers. Manag. 2014, 87, 164-174. [CrossRef]

8. Franco, A.; Versace, M. Optimum sizing and operational strategy of CHP plant for district heating based on the use of composite indicators. Energy 2017, 124, 258-271. [CrossRef]

9. Chartered Institution of Building Services Engineers (CIBSE). Combined Heat and Power for Buildings (CHP)-AM12. 2016. Available online: https:/ / www.cibse.org/ (accessed on 23 April 2018).

10. Higher Education Statistics Agency. Environmental Information, Estates Management Statistics Tables. Available online: https: / / www.hesa.ac.uk/index.php?option=com_heicontacts\&Itemid=87 (accessed on 10 October 2016).

11. Amber, K.P.; Parkin, J. Barriers to the uptake of combined heat and power technology in the UK higher education sector. Int. J. Sustain. Energy 2015, 34, 406-416. [CrossRef]

12. Hinojosa, L.R.; Day, A.R.; Maidment, G.G.; Dunham, C.; Kirk, P. A comparison of combined heat and power feasibility models. Appl. Therm. Eng. 2007, 27, 2166-2172. [CrossRef]

13. Wu, Q.; Ren, H.; Gao, W.; Ren, J. Multi-criteria assessment of building combined heat and power systems located in different climate zones: Japan-China comparison. Energy 2016, 103, 502-512. [CrossRef]

14. Carbon Trust, Combined Heat and Power for buildings, Good Practice Guide, CPG388. 2012. Available online: http:/ / www.cwp-ltd.com/wp-content/uploads/2012/03/UKGoodPracticeGuide.pdf (accessed on 20 November 2012).

15. Charter Institute of Building Services Engineers (CIBSE). Introducing CHP. 2012. Available online: https:// www.cibse.org/getmedia/373712aa-96a1-479a-842e-4e71f241b707/Introducing-CHP.pdf.aspx (accessed on 24 January 2016).

16. Burns, C. ENER-G Combined Power Blog, CHP in Your CPD: What Building Engineers Need to Know about Cogeneration. Available online: http:/ /chpblog.energ-group.com/chp-in-your-cpd-what-buildingengineers-need-to-know-about-cogeneration (accessed on 15 December 2016).

17. Hamzehkolaei, F.T.; Amjady, N. A techno-economic assessment for replacement of conventional fossil fuel based technologies in animal farms with biogas fuelled CHP units. Renew. Energy 2018, 118, 602-614. [CrossRef]

18. Shenton Group. What Is G59. Available online: http://www.shentongroup.co.uk/wp-content/uploads / 2013/07/The-G59-Process-A-Simple-Overview-V4.pdf (accessed on 13 November 2012).

19. Amber, K.P.; Aslam, W.; Bashir, M.A. Development of a Typical Hourly Electricity Consumption Profile for Student Residence Halls Based on Central Tendency Method. Nucleus 2016, 53, 14-25. 
20. Carbon Trust, Introducing Combined Heat and Power. Available online: https:/ / www.carbontrust.com/ media/19529/ctv044_introducing_combined_heat_and_power.pdf (accessed on 21 October 2013).

21. Amber, K.P. Development of a Combined Heat and Power Sizing Model for the Higher Education Sector of the United Kingdom. Ph.D. Thesis, London South Bank University, London, UK, 2013.

22. Amber, K.P.; Dunn, A.; Parkin, J.; Day, A.R. Development of a combined heat and power sizing model for higher education buildings in the United Kingdom. Energy Build. 2018. [CrossRef]

23. Maurovich-Horvat, L.; Rocha, P.; Siddiqui, A.S. Optimal operation of combined heat and power under uncertainty and risk aversion. Energy Build. 2016, 110, 415-425. [CrossRef]

24. TeymouriHamzehkolaei, F.; Sattari, S. Technical and economic feasibility study of using Micro CHP in the different climate zones of Iran. Energy 2011, 36, 4790-4798. [CrossRef]

25. Wickart, M.; Madlener, R. Optimal technology choice and investment timing: A stochastic model of industrial cogeneration vs. heat-only production. Energy Econ. 2007, 29, 934-952. [CrossRef]

(C) 2018 by the authors. Licensee MDPI, Basel, Switzerland. This article is an open access article distributed under the terms and conditions of the Creative Commons Attribution (CC BY) license (http://creativecommons.org/licenses/by/4.0/). 